Check for updates

New York

Cite this as: $B M J 2020 ; 371: \mathrm{m} 4154$ http://dx.doi.org/10.1136/bmj.m4154 Published: 27 October 2020

\title{
Covid-19: Virus is out of control, White House admits
}

\section{Janice Hopkins Tanne}

As cases of covid-19 in the United States continue to surge, the scientific adviser to the president has suggested that the time may have come to mandate mask wearing.

The White House chief of staff, Mark Meadows, admitted on 25 October that covid-19 infections were out of control in the US. "We're not going to control the pandemic. We are going to control the fact that we get vaccines, therapeutics, and other mitigations, because it is a contagious virus, just like the flu," he said in a CNN interview. ${ }^{1}$

Covid-19 cases have surged over the past few weeks, with about 75000 new cases a day. The US, which currently has the world's largest epidemic, has reported 8.7 million cases and 225588 deaths as of 26 October. $^{2}$

Anthony Fauci, head of the National Institute for Allergy and Infectious Diseases who advises the president on the pandemic, told CNN on 23 October that it may be time to require masks. "There's going to be a difficulty enforcing it," he said, but it "would be a great idea to have everybody do it uniformly," along with social distancing and frequent handwashing. ${ }^{3}$

Fauci's comments came just days before Amy Coney Barrett was approved by the Senate for a lifetime appointment to the Supreme Court and sworn in on 26 October. She replaces the late Ruth Bader Ginsburg and gives the court a 6-3 conservative majority. Barrett will soon rule on important health and election issues.

\section{Pre-existing conditions}

Barrett's appointment is important to the future of healthcare for Americans because, on 10 November, the Supreme Court will rule on a case brought by the Trump administration that would overturn the Affordable Care Act, widely known as Obamacare.

The act provides health insurance to about 20 million Americans and guarantees that insurance cannot be denied for pre-existing conditions. Infection with covid-19, which leads to long term problems in some people, would be considered a pre-existing condition.

The court may also rule on cases related to the upcoming 3 November election if President Donald Trump loses and challenges the outcome over issues such as counting ballots and the validity of mail-in ballots in at least four states. Other important issues soon to come before the court involve the president's tax returns, which he is trying to protect from a New York inquiry; LGBTQ rights; and access to abortion, which was established by the court's Roe $v$ Wade decision in 1973.

In the White House cases have erupted among the staff of Vice President Mike Pence, who heads the
White House's coronavirus task force. Pence has continued campaigning despite quarantine guidelines from the Centers for Disease Control and Prevention, as the White House declared him an "essential worker."

On 25 October the White House revealed that five of Pence's staff had tested positive for covid-19, including his chief of staff and four other close aides. This is the third outbreak in the White House, after an episode in May and a "super spreader" event on 26 September, at which Barrett was honored and at which Trump was apparently infected.

Despite the infections among his close contacts Pence continued campaigning, making visits to Minnesota, North Carolina, and Florida. Guidelines from the Centers for Disease Control and Prevention recommend that people who have been in close contact with an infected person should self-quarantine for at least 14 days.

Kamala Harris, the Democratic nominee for vice president, quarantined for several days after a staff member, with whom she was not in close contact, tested positive for covid-19.

CNN. State of the Union. 25 Oct 2020. https://www.cnn.com/shows/stateof-the-union.

2 Center for Systems Science and Engineering, Johns Hopkins University. Covid-19 dashboard. 2020. https://gisanddata.maps.arcgis.com/apps/opsdashboard/index.html\#/bda7594740fd40299423467b48e9ecf6.

3 Kane A, Fox M. Fauci says it might be time to mandate masks as covid-19 surges across US. CNN Health 2020 Oct 24 https://www.cnn.com/2020/10/23/health/fauci-covid-mask-mandatebn/index.html.

This article is made freely available for use in accordance with BMJ's website terms and conditions for the duration of the covid-19 pandemic or until otherwise determined by BMJ. You may use, download and print the article for any lawful, non-commercial purpose (including text and data mining) provided that all copyright notices and trade marks are retained. 